\title{
The Oppressive Sexist Male Language: A Feminist Portrayal of the English Language
}

\author{
Maxwell C.C. Musingafi ${ }^{1 *} \quad$ Racheal Mafumbate $^{2} \quad$ Thandi F. Khumalo ${ }^{3}$ \\ 1.Zimbabwe Open University, Department of Development Studies, Faculty of Applied Social Sciences \\ 2.University of Eswatini, Department of Educational Foundations and Management, Faculty of Education \\ 3.University of Eswatini, Department of Sociology and Social Work, Faculty of Social Sciences
}

\begin{abstract}
In this paper, we examine the various ways in which language portrays a negative image of women. We argue that this state of affairs is of great concern to feminists. We identify ways in which language has been found wanting in as far as women are concerned. Firstly, language, especially the English language, is accused of creating false gender neutrality because this purported neutrality ends up showing a bias towards maleness. Feminists further argue that the English language makes women invisible and always overshadowed by men. The language is accused of making maleness the standard measure of humanity and maturity. As such, maleness is seen as the norm. They further argue that sex-marking common in the English language encourages male visibility and powerlessness of women in a male dominated world. As a result, the world is seen through an oppressive male worldview. Reform efforts have been piecemeal and as such have largely failed to reach the desired destination. Critics argue that these claims concerning the maleness of the English language are contentious, as they tend to be exaggerated, unrealistic and problematic.
\end{abstract}

Keywords: Feminism, language, male, oppressive, sexist, portrayal, English

DOI: $10.7176 / \mathrm{JCSD} / 47-06$

Publication date: April $30^{\text {th }} 2019$

\section{Introduction}

Feminists argue that language creates a negative impression of women. They argue that language sees women as nothing more than sex objects. In this paper, we examine some of the language issues of concern to feminists. We examine these issues starting with what they call false gender neutrality, followed by invisibility of women, maleness as norm, sex-marking, encoding of male worldview, reform efforts, maleness of language, metaphor and generics respectively.

\section{False gender-neutrality}

According the Saul (2017), there has been a great deal of feminist concern over the supposedly gender-neutral use of terms like 'he' and 'man'. It is believed that these terms have both gender-specific meanings, as in sentences (1) and (2), and gender-neutral ones, as in sentences (3) and (4).

1. He drank the wine.

2. A man went into a bar.

3. When a student comes into the room, he should pick up a handout.

4. Man is a primate.

Feminists, however, have pointed out that even the supposed gender-neutral meanings of these terms are not really gender-neutral. Moulton (1981a) and Mercier (1995) provide examples in which there is no doubt that a gender-neutral meaning is intended, but this meaning seems unavailable. As a result, the sentences seem illformed:

5. Man has two sexes; some men are female.

6. Man breastfeeds his young.

We are making a classificatory error if we claim that 'man' and 'he' are gender-neutral terms. Mercier (1995) suggests that we should understand the 'gender-neutral' use of 'man' as referring to either (a) a person or persons of unknown sex; or (b) males or a combination of males and females. This explains why 'men' in (5) and 'man' in (6) are anomalous: these terms are being used to refer exclusively to persons known to be female. The supposed 'gender-neutral' meaning of these terms, then, is not truly gender neutral. But, on its own, this does not show that there is a problem with those uses that have traditionally been classified as gender-neutral, as in sentences (3) and (4).

\section{Invisibility of women}

Feminist concerns, however, go beyond mere classificatory ones. Feminists have also argued that terms like 'he' and 'man' contribute to making women invisible, that is, to obscuring women's importance, and distracting attention from their existence. Fighting the invisibility of women is an important feminist project in many areas, and language that makes one less likely to think of women clearly contributes to this invisibility (Saul, 2017). 
There is good psycholinguistic evidence that those who encounter sentences using the terms 'he' and 'man' think more readily of males than of females (ibid). If this is right, then the use of these words can be seen as contributing to the invisibility of women. This gives feminists a good reason to object to the 'gender-neutral' use of these terms.

\section{Maleness as norm}

If one's only worry concerned the obscuring of women's presence, however, it would be difficult to object to certain other terms to which feminists do commonly object: gender-specific occupational terms like 'manageress' or 'lady doctor'. These terms certainly do not contribute to the invisibility of women. Instead, they call attention to the presence of women. Moreover, they call attention to women's presence in positions of authority-doctor and manager. Nonetheless, most feminists who think about language find these terms objectionable (Saul, 2017).

The clearest reason for objecting to 'manageress' and 'lady doctor' is that the use of these terms seems premised on the idea that maleness is the norm, and that women filling these jobs are somehow deviant versions of doctors and managers. This is also a key objection to the use of 'he' and 'man'. Moulton (1981a) understands these terms on the model of brand names, like 'Hoover' or 'Scotch tape' that become generic terms for a product type. The message of such terms, she suggests, is that the brand in question is the best, or at least the norm. According to Moulton (1981a), terms like 'he' and 'man' work in the same manner. They are gender-specific terms for men whose use has been extended to cover both men and women. This carries the message that maleness is the norm. As a result, the use of these terms as if they were gender neutral constitutes a sort of symbolic insult to women. Horn and Kleinedler (2000) have disputed the details of this, noting that 'man' did not begin its life as gender-specific and then get extended to cover both women and men. Rather, 'man' actually began its life as 'mann', a gender-neutral term, which only later acquired a gender-specific meaning. The temporal sequence, then, cannot support the claim that a gender-specific term has been extended to cover both genders. Nonetheless, Horn and Kleinedler (2000) agree that the use of terms like 'he' and 'man' as if they were gender-neutral perpetuates the objectionable idea that men are the norm for humanity.

\section{Sex-marking}

English, like most, but not all languages, requires a great deal of what Frye (1983) calls 'sex marking'. For example, one cannot use pronouns to refer to a particular individual without knowing their sex. Singular personal pronoun usage, Frye (1983) argues, is impossible without knowing the sex of the person one is discussing, and in many cases, sex would otherwise be utterly irrelevant. She takes this to be an instance of a general tendency to make sex relevant where it needs not be, which she takes to be a key feature of sexism. In addition, she suggests, the constant need to know and indicate sex helps to perpetuate the conviction that sex is a tremendously important matter in all areas. For Frye, this is a key factor in perpetuating male dominance. Male dominance requires the belief that men and women are importantly different from each other, so anything that contributes to the impression that sex differences are important is therefore a contributor to male dominance.

\section{Encoding of male worldview}

The meanings of certain terms seem to divide the world up in a way that is more natural for men than for women (Cameron 1985; Moulton 1981b; Spender 1980; 1985). They argue that good examples of this come from the terms 'foreplay' and 'sex'. 'Sex' is generally taken to refer to an act that is defined in terms of male orgasm, while the sexual activities during which many women have their orgasms are relegated to secondary status, referred to by terms like 'foreplay'. These terms are thus, seen as based in a male perspective on sex. MacKinnon (1989) and Haslanger (1995) also discuss legal definitions of 'rape' as involving more than 'the normal level of force', an understanding that seems committed to the idea that some level of force is acceptable in sexual relations.

According to Farley (1978) and Spender (1985), languages may also lack words for things that matter a great deal to women. They argue that this sort of gap is another way that a language can be seen as encoding a male worldview. The term 'sexual harassment', for example, is a recent feminist innovation. Women's discussion of their experiences led them to see a certain common element to many of their problems, and as a result they invented the term 'sexual harassment'. Once the problem was named, it became much easier to fight sexual harassment, both legally and by educating people about it (Farley, 1978; Spender, 1985).

Fricker (2007) calls gaps such as that before the invention of the term 'sexual harassment' a form of hermeneutical injustice. Roughly speaking, this is what occurs when some significant area of one's social experience is obscured from collective understanding owing to a gap in communal linguistic/conceptual resources that is more damaging to those from a socially disadvantaged group to which one belongs (Fricker, 2007). 


\section{Reform efforts}

Problems like those we have seen so far are relatively easy to discern. Much feminist effort has been devoted to rectify them, and a huge variety of reforms have been proposed. One reform effort has been the increasingly accepted singular use of the third-person gender-neutral pronoun 'they' in place of 'he' as in the following sentence: Somebody left their sweater behind. Other reform efforts have met with greater difficulties. Even some that have caught on seem to have backfired. Erlich and King (1998), for example, discuss the case of 'chairperson', intended to serve as a gender-neutral replacement for 'chairman'. Instead, in many places it is often used to indicate women who fill the post of chair, while men are referred to as 'chairman'. They take this to show that reforms cannot succeed unless attitudes change as well.

Moreover, feminist work on language has also indicated that there may be problems which are simply not amenable to piecemeal linguistic reforms. Some difficulties that have been raised go well beyond a handful of problematic terms or gaps. Cameron (1985: 85) offers striking examples of writing that take males as the norm without using any particular terms to which one might object, such as the following: "The lack of vitality is aggravated by the fact that there are so few able-bodied young adults about. They have all gone off to work or look for work, leaving behind the old, the disabled, the women and the children".

Clearly, in the above example, 'able-bodied young adult' is being used in such a way as to exclude women. Moreover, examples like this pass unnoticed by newspaper editors and many readers. There is clearly a problem, but it is not a problem that can be pinpointed by picking out some particular term as objectionable and in need of reform. Eliminating language use that takes males as the norm, then, must involve more than changing a few terms or usage rules (Saul. 2017).

\section{Maleness of language}

Some feminists (Penelope, 1990; Spender, 1985) argue that English is, in some quite general sense, male. One thing that is meant by this is that English can be said to be male in a manner similar to that in which particular terms can be said to be male - by encoding a male worldview, by helping to subordinate women or to render them invisible, or by taking males as the norm. The male bias of English is so widespread that it is a mistake to locate the problem in a collection of words, rather than in the language as a whole. According to Saul (2017), the sorts of claims (in addition to those we have already seen) cited include:

- $\quad$ there are more words for males than for females in English (Spender, 1985: 15;

- a "word for women assumes negative connotations even where it designated the same state or condition as it did for men" (Spender, 1985: 17), as with 'spinster' and 'bachelor'; and

- words for women are far more frequently sexualized than words for men. This holds true even for neutral words, when they are applied to women. Spender (1985) discusses the example of 'professional', comparing 'he is a professional' and 'she is a professional', and noting that the latter is far more likely than the former to be taken to mean that the person in question is a prostitute.

This widespread encoding of male bias in language is, according to Spender (1985), just what we should expect. Males have had far more power in society, and this has included the power to enforce, through language, their view of the world. There is sexism in language (Spender, 1985).

Some feminists have argued that the only way for women to get freedom from the oppressive male language is to create their own language, either by redefining terms already in use, or by inventing a new language, with new words and new rules (Daly and Caputi, 1987; Elgin, 1985; MacKinnon, 1989; Penelope, 1990; Spender, 1985).

\section{Metaphor}

An important topic of feminist concern has been the historical tendency to conceive of the scientific endeavour in gendered ways. A particularly clear example comes from Keller (1996) and Lloyd (1984). Science is expressed as 'leading you to Nature with all her children to bind her to your service and make her your slave' (Keller, 1996: 36). The tendency to describe nature in feminine terms is a long-standing and widespread one, well-documented in Lloyd (1984). Lloyd links this to a tendency to describe reason and the mind as male, and to contrast these with supposedly feminine emotions and bodies. She argues that these metaphors play a powerful role in the history of philosophy, shaping and often distorting our views both of reason, mind, emotion, and body and of men and women.

\section{Generics}

Generic statements are ones such as "cats are furry", or "a cat has fur", which are neither universal generalizations (there are furless cats) nor existential generalization (the claim being made is clearly stronger). Of key interest here are examples such as "boys don't cry" or "women place their families before their careers". These sentences can be used to express merely descriptive claims; describing, for example, crying as something not that many boys do. But they can also be used to make normative claims about what boys or women should 
do. Wodak, Leslie, and Rhodes (2015: 659) suggest that "we can understand the difference between normative and descriptive generics in terms of the different concepts picked out by the noun phrase in the generics themselves". 'Woman' may pick out a normative concept - an ideal, which might include such things as a focus on family over career; or, alternatively, it may pick out a descriptive concept, and refer to women regardless of whether they focus on family over career. Leslie uses this as a foundation for explaining utterances like "Hillary Clinton is the only man in the Obama White House", suggesting that 'man' here refers to the ideal of manliness. It is also a part of a more general project of arguing that generic utterances have harmful effects on social cognition. Leslie, as captured in Saul (2017) also discusses what she calls "striking property generics", statements that attribute dangerous properties to groups generically specified like "black people are dangerous" or "Muslims are terrorists". She argues that striking property generic claims may not require many instances to be accepted as true (assuming some other conditions are also met) allowing them to serve as a key mechanism in perpetuating and exacerbating prejudice.

Haslanger (2011) has built on Leslie's work, arguing that generic claims often carry conversational implicatures about natures, and that these help them to serve as a key mechanism for perpetuating the ideologies that hold unjust social structures in place. She suggests that whatever their truth conditions one should deny them via the mechanism of meta-linguistic negation (Horn, 1985) which allows the denial of a claim because it carries a false implicature. By this method, we can start to disrupt the ideologies that have us in their grip.

\section{Criticisms}

According to Saul (2017), the claims concerning the maleness of English, its causes, and its effects, are contentious. First, the extent of male bias in language is debatable. Although it is right that there is much to worry feminists about a wide variety of specific terms and usages, it is far from clear that it is appropriate to claim that English is male-biased in some sweeping sense. It is also unclear exactly what the claim being made is. If this claim is taken to be that every term is male-biased, then it is highly implausible. If the claim is simply that there is much for feminists to object to, then it is almost certainly right — but it is far from obvious that it is useful to focus on such a general claim rather than on specific problems, their complexities and their possible solutions (Cameron, 1998).

Saul (2017) argues that the power that men have undeniably exercised in society by no means translates to a general power over language. Language is a difficult thing to control. The main power men have had has concerned dictionaries, usage guides, and laws. While these are enormously important in shaping reality, and in shaping our thoughts, it is quite a leap to move from this power to the claim that men 'created language, thought, and reality' (Saul, 2017).

Saul (2017) further argues that the claimed effects of the maleness of language are also problematic. We have already seen problems for the idea that men control language. The idea that men also control or create thought and reality faces further problems. The ability of feminists to successfully point out ways in which elements of language have obscured women's experiences counts strongly against the claim that men control thought (Cameron, 1998) and, as Haslanger (1995) has argued in detail, discursive constructivism about reality is unsustainable. Nonetheless, it does seem right to notice that problems with specific terms can render it more difficult for women to communicate about important elements of their lives, and probably also more difficult to reflect upon these elements (Hornsby, 1995). These difficulties could perhaps be described as partial silencing, partial constraint of thought, or hermeneutical injustice (Fricker, 2007).

If the criticisms above are right, then women certainly do not need to create their own language. Many welcome this conclusion, worried that a women's language would doom women's thoughts to marginality and impede feminist progress. Moreover, the idea that women could craft a common language that allowed the articulation of all their experiences seems to ignore the fact that women differ enormously from one another (Crenshaw, 1991; Lugones and Spelman, 1983; Spelman, 1988). If women cannot use the same language as men, why should we suppose that women can successfully share a language?

\section{Conclusion}

In this paper, we have examined the various ways in which language portrays a negative image of women. We argued that this state of affairs is of great concern to feminists. Language has been accused of creating false gender neutrality, making women invisible, making maleness the standard measure of humanity and maturity, encouraging and male visibility and powerlessness of women in a male dominated world. In fact, the world is seen through an oppressive male worldview. Reform efforts have been piecemeal and as such have largely failed to reach the desired destination.

\section{References}

Cameron, D. (1985). Feminism and linguistic theory, Basingstoke and London: MacMillan.

Cameron, D. (1998). "Feminist linguistic theories", in S. Jackson and J. Jones (eds.), Contemporary feminist 
theories, Edinburgh: Edinburgh University Press, pp. 147-161.

Crenshaw, K. (1991). "Mapping the margins: Intersectionality, identity politics, and violence against women of colour", Stanford Law Review, 43(6): 1241-1299.

Daly, M. and Caputi, J. (1987). Websters' first new intergalactic wickedary of the English language, Boston: Beacon Press.

Elgin, S.H. (1985). A first dictionary and grammar of Láadan, Madison: Society for the Furtherance and Study of Fantasy and Science Fiction.

Erlich, S. and King, R. (1998). "Gender-based language reform and the social construction of meaning", Cameron, D. (1998). "Feminist linguistic theories", in S. Jackson and J. Jones (eds.), Contemporary feminist theories, Edinburgh: Edinburgh University Press. 164-179.

Farley, L. (1978), The sexual shakedown: the sexual harassment of women on the job, New York. McGraw-Hill. Fricker, M. (2007), Epistemic injustice: Power and the ethics of knowing, Oxford. Oxford University Press.

Frye, M. (1983). The politics of reality: Essays in feminist theory, freedom. Trumansburg. NY: The Crossing Press.

Haslanger, S. (1995). "Ontology and social construction”, Philosophical topics, 23(2): 95-125.

Haslanger, S. (2011). "Ideology, generics, and common ground", in C. Witt (ed.). (2011). Feminist Metaphysics, Dordrecht: Springer Verlag. Pp: 179-207.

Horn, L.R. (1985). "Metalinguistic negation and pragmatic ambiguity", Language, 61(1): 121-174.

Horn, L.R. and Kleinedler, S.R. (2000). "Parasitic reference vs. R-based narrowing: Lexical pragmatics meets he-man", paper presented to the Linguistic Society of America, Chicago, 6 January, available online.

Hornsby, J. (1995). "Disempowered speech", Philosophical topics, 23(2): 127-147.

Keller, E.F. (1996). "Feminism and science". in E.F. Keller and H. Longino (eds.). (1996). Feminism and science, Oxford: Oxford University Press. Pp: 28-40.

Lloyd, G. (1984). The man of reason: 'Male' and 'female' in western philosophy. Minneapolis. University of Minnesota Press.

Lugones, M. and Spelman, E. (1983). "Have we got a theory for you! Feminist theory, cultural imperialism, and the demand for 'the woman's voice'”. Women's studies international forum. 6(6): 573-581.

MacKinnon, C.A. (1989). Toward a feminist theory of the state, Cambridge, MA: Harvard University Press.

Mercier, A. (1995). "A perverse case of the contingent a priori: On the logic of emasculating language (A reply to Dawkins and Dummett)". Philosophical topics. 23(2): 221-259.

Moulton, J. (1981a). "The myth of the neutral 'man"”. in Vetterling-Braggin, M. (ed.). (1981). Sexist language: A modern philosophical analysis. Totowa, NJ: Littlefield and Adams.: 100-115.

Moulton, J. (1981b). "Sex and reference". in Vetterling-Braggin, M. (ed.). (1981). Sexist language: A modern philosophical analysis: 183-193.

Penelope, J. (1990). Speaking freely: Unlearning the lies of the fathers' tongues. New York, NY: Pergamon.

Saul, J. (2017). Feminist philosophy of language. The Stanford Encyclopedia of philosophy. The Metaphysics Research Lab. Centre for the Study of Language and Information (CSLI), Stanford University.

Spelman, E.V. (1988). Inessential woman, Boston: Beacon Press.

Spender, D. (1985). Man made language. (second edition). New York: Routledge.

Wodak, D. Leslie, S.J. and Rhodes, M. (2015). "What a loaded generalization: Generics and social cognition", Philosophy compass, 10(9): 625-635. 